\title{
Exploring Writing Anxiety of the EFL University Students in Pontianak Indonesia
}

\author{
Aunurrahman \\ IKIP-PGRI Pontianak, Indonesia \\ e-mail: yarrha@gmail.com
}

\begin{abstract}
:
The purpose of the descriptive study is to explore the English as a foreign language second-semester students' writing anxiety. The students were from a private university in Pontianak, West Kalimantan, Indonesia. A total of 92 students who were selected randomly filled the writing anxiety questionnaire. The writing anxiety questionnaire reports that $53.26 \%(n=49)$ of the students experienced low writing anxiety and $46.74 \%(n=43)$ of the students experienced high writing anxiety. In terms of the components of writing anxiety, the students experienced anxiety in the component of evaluation (mean score of 19.86), product (mean score of 19.25), and stress (mean score of 16.52). This study also has shown that writing anxiety caused by stress can be considered less frequent anxiety component that has been experienced by the students. It is suggested that students should learn to manage their problems that are related to writing. To do so, the lecturer should guide the students to help them to reduce their writing anxiety and help improve the students' writing skills.
\end{abstract}

Keywords: individual differences, tertiary EFL students, writing anxiety

\section{Introduction}

Writing has an important purpose, that is, to achieve communication in written forms. The written forms composed should be organized properly, written accurately, and meaningful for the readers (Emilia, 2005, 2010; Emilia \& Hamied, 2015). Organization, accuracy, and meanings are only some elements that are demanded by particular readers in certain contexts. For example, academic or scientific writing is demanded in academic institutions such as universities.

Learning or even acquiring those components of writing is not an easy task (Fareed, Ashraf, \& Bilal, 2016; Grabe \& Kaplan, 1998, p. 6; Klimova, 2014). Accordingly, learning to write a piece of written text for a certain context or a purpose takes time and efforts (Emilia, 2009; Emilia \& 
Hamied, 2015; Oshima \& Hogue, 1999). During the process, students may encounter obstacles such as language barriers that could lead to anxiety (see Toba, Noor, \& Sanu, 2019). An example is students can feel anxious when the lecturer or the teacher gives them feedback.

Previous studies on writing anxiety around the world had been conducted. For example, in Turkey, a study explored the writing anxiety experienced by secondary school students. The study reported that female students tended to experience writing anxiety rather than male students (Çocuk, Yelken, \& Özer, 2016). A qualitative study on writing anxiety also had been conducted in Afghanistan. The qualitative study reported that writing anxiety could be facilitating and debilitating the students' capability in writing in the English language due to limited practices and activities that they had done (Miri \& Joia, 2018).

In Indonesia, many previous studies on anxiety in different contexts had been conducted. For example, Ariyanti (2017) used the term foreign language anxiety to describe students' anxiety in Samarinda where she found that the students' anxiety mainly gave negative effects to their performance in writing. Some similar studies also showed that anxiety gave negative effects to students' performance in learning English as a foreign language (Hidayati, 2018), including learning the skills of the English language such as speaking (Aghajani \& Amanzadeh, 2017; Anandari, 2015; Sutarsyah, 2017) and writing (Kusumaningputri, Ningsih, \& Wisasongko, 2018; Rahim, Jaganathan, \& Mahadi, 2016; Wahyuni \& Umam, 2017). Nevertheless, anxiety does not always debilitating or giving negative effects to students' performance in writing as shown earlier by Miri \& Joia (2018). Instead, anxiety could help students to perform better in writing (see Rudiyanto, 2017; Sundari \& Febriyanti, 2017).

The previous studies shown above have inspired the writer to explore the tertiary English as a foreign language students' writing anxiety as well. The difference with the earlier studies is the study was conducted to the second-semester students of a private university in the context of Pontianak, West Kalimantan, Indonesia. The study on writing anxiety in this context was still limited. Another difference with the previous studies is this study used its own writing anxiety questionnaire. Nevertheless, the components and some items of the writing anxiety questionnaire are based on the work of Daly and Miller (1975).

\section{Literature Review}

Anxiety in writing can be called as writing anxiety. It is regarded as a specific form of anxiety because writing anxiety is limited to a particular language learning situation (Horwitz, Horwitz, \& Cope, 1986, p. 125). Besides writing anxiety, the term writing apprehension can also describe apprehension or anxiety in writing (see Susoy \& Tanyer, 2013). Both terms are used interchangeably in this paper.

Generally, there are many categories of anxiety. For example, Dörnyei (2005, p. 198) categorizes anxiety to facilitating anxiety and debilitating anxiety; and trait and state anxiety. Other categories of anxiety are communication apprehension, test anxiety, and fear of negative evaluation (see Horwitz et al., 1986). Also, Cheng (2004) proposes three components of writing anxiety, namely physiological (somatic), cognitive and behavioral components. However, the writer sees that the components are still not too specific.

Other three components under the term writing apprehension are based on the work of Daly and Miller (1975). The components are as follows: 
1. Evaluation apprehension. This component shows that students feel that they will not be able to do their best as they believe that they do not have proper skills to write.

2. Stress apprehension. This component shows that students feel fear to begin to write. Due to the stress, the students may procrastinate and experience writers' block.

3. Product apprehension. This component shows that producing a piece of writing is not important for students. The students will only write a single text without doing any revisions to make it better.

This study sees that the components proposed by Daly and Miller (1975) are very specific to the context of the study as they deal with anxiety that occurs in a specific situation that is in writing using a second language or a foreign language, in this case, English language. Even though, anxiety seems to bring negative influence to the person who is undergoing a writing process writing (Thompson cited in Kurt \& Atay, 2007), the writer believes that anxiety does not always bring negative influence that will reduce the students' capacity in writing (see Dörnyei, 2005; Miri \& Joia, 2018; Piniel \& Csizér, 2013; Williams, 2008).

\section{Research Methodology}

This is a descriptive study that explores the tertiary English as a foreign language (hereafter EFL) students' writing anxiety. The descriptive study is a form of survey that allows a researcher to collect opinions or attitudes of a particular population. These opinions or attitudes could provide descriptions of the population (Creswell, 2012) in a certain context, in this case, a writing anxiety context. The population of this study is the second-semester students of a private university. The students' major is English Education and the private university is located in Pontianak, West Kalimantan, Indonesia.

The numbers of the population of this research were 127 students. Not all of the students took part in this study. A simple random sampling technique where each member of the population under study has an equal chance of being selected (Fraenkel, Wallen, \& Hyun, 2011) was used to select the students or participants who would be administered the writing anxiety questionnaire. The numbers of the participants in this research were 92 students. Krejcie and Morgan table (cited in Cohen, Manion, \& Morrison, 2007) was used to determine the numbers of the participants.

To collect data about the students' writing anxiety, the writer administered a written questionnaire. There are three different and independent components of writing anxiety that were used in this study, namely evaluation, stress, and product apprehension or anxiety (see Daly \& Miller, 1975). Based on these components, a written questionnaire is constructed to measure the degree to which a student feels anxious when writing in the English language.

Before administering the questionnaire, validity and reliability of the instrument were examined. To do this, a try out has been conducted to the students who did not belong to the sample. The tryout questionnaire contained 30 items which were answered on a Likert scale. The scale range is from 'strongly agree' to 'strongly disagree.' Some items of the questionnaire are adapted from Daly and Miller's instrument (1975). The blueprint of the questionnaire is illustrated below: 
Table 1: Blueprint of the questionnaire

\begin{tabular}{l|l|l|l|c}
\hline No. & Aspects & Indicators & \multicolumn{1}{|c}{ Item number } & Number of item \\
\hline 1. & Evaluation & fear of being evaluated & $\begin{array}{l}1,4,8,11,15,18,20, \\
23,26,29\end{array}$ & 10 \\
\hline 2. & Stress & avoiding writing process & $\begin{array}{l}2,5,7,10,14,17,19, \\
22,25,30\end{array}$ & 10 \\
\hline 3. & Product & $\begin{array}{l}\text { a sense that writing is not an } \\
\text { important activity }\end{array}$ & $\begin{array}{l}3,6,9,12,13,16,21, \\
24,27,28\end{array}$ & 10 \\
\hline & & Total of item & & 30 \\
\hline
\end{tabular}

The scores of the try out were examined its validity and reliability. In relation to validity issue, the results of the try out indicate that twenty four out of thirty items of the writing anxiety questionnaire are valid. The valid items are number $1,2,3,5,6,9,11,12,13,14,15,16,18,19,20$, $21,22,23,24,25,26,28,29,30$. In relation to the reliability issue, the coefficient of reliability of writing anxiety questionnaire is 0.92 . It is higher than r-table for $\mathrm{N}=40$ at $5 \%$ level of significance (0.312). This means that the questionnaire is reliable. After the instrument is considered valid and reliable, it could be used to measure the degree to which the participants feel anxious when writing in the English language.

The completion of the data collection is followed by data analysis. The students' responses to the writing anxiety questionnaire were transferred to databases (spreadsheets) to explore the writing anxiety that was experienced by the students. This has enabled the data to be analyzed quantitatively. The statistical procedures are: (1) The descriptive statistics were used to rank the order of the writing anxiety categories from the high anxiety to the low anxiety categories. Then, (2) the descriptive statistics were also used to analyze the students' responses obtained from the questionnaire. The overall average score shows how often the learners are feeling anxious, while the mean score for each writing anxiety statement of the questionnaire stands for which writing anxiety the learners feel frequently. The findings of the study will be elaborated in the following section.

\section{Findings and Discussion}

\subsection{Findings}

To answer the research problem of the study, the writer distributed the writing anxiety questionnaire to the students to collect their responses. The writing anxiety questionnaire consists of 24 items. Each item represents a statement of writing anxiety which the students feel when the students are writing in the English language. The data analysis shows that the highest score is 89 , meanwhile, the lowest score is 25 . Then, the range is 64 with the number of classes 7 and the class interval 10 . The frequency distribution of the writing anxiety questionnaire score can be seen in Table 2 .

Table 2: Frequency distribution

\begin{tabular}{c|c|c|c|c}
\hline Class limits & Class boundaries & Midpoint & Frequency & \% \\
\hline $25-34$ & $24.5-34.5$ & 29.5 & 1 & 1,09 \\
\hline $35-44$ & $34.5-44.5$ & 39.5 & 10 & 10,9 \\
\hline $45-54$ & $44.5-54.5$ & 49.5 & 34 & 37 \\
\hline
\end{tabular}




\begin{tabular}{c|c|c|c|c}
\hline $55-64$ & $54.5-64.5$ & 59.5 & 33 & 35,9 \\
\hline $65-74$ & $64.5-74.5$ & 69.5 & 11 & 12 \\
\hline $75-84$ & $74.5-84.5$ & 79.5 & 2 & 2,17 \\
\hline $85-94$ & $84.5-94.5$ & 89.5 & 1 & 1,09 \\
\hline & & & $\mathbf{9 2}$ & $\mathbf{1 0 0}$ \\
\hline
\end{tabular}

Table 2 shows that the students could be classified into students who had experienced low writing anxiety and high writing anxiety based on the overall mean score $(\mathrm{om}=55.63)$. It is important to note that the higher the score is the higher the writing anxiety is. Meanwhile, the lower the score is the lower the writing anxiety is. From the total sample of 92 students, 49 students (53.26\%) were categorized into the low writing anxiety group with scores ranging from 25 to 55 . Then, 43 students $(46.74 \%)$ were categorized into the high anxiety group with scores ranging from 56 to 89.

Mainly, the students had experienced low writing anxiety (53.26\%) rather than high anxiety (46.74\%). This means that the students could cope with writing anxiety. The finding is in line with the previous study by Miri \& Joia (2018) that shows anxiety could facilitate learning, in this case, learning writing in the English language. To see how writing anxiety could facilitate and debilitate learning writing, this study goes further by describing the writing components that had been experienced by the students in the following table.

Table 3: Writing anxiety components that had been experienced by the students

\begin{tabular}{c|c|c|c|c}
\hline & Evaluation & Stress & Product & OM \\
\hline TS & 1827 & 1520 & 1771 & 1706 \\
\hline Mean & 19.86 & 16.52 & 19.25 & 18.54 \\
\hline SD & 3.87 & 3.21 & 4.18 & 3.75 \\
\hline
\end{tabular}

Note:

TS $\quad=$ Total Score

$\mathrm{SD}=$ Standard Deviation

$\mathrm{OM}=$ overall mean

Table 3 shows that the most writing anxiety component that had been experienced by the students is evaluation anxiety with a mean score of 19.86, followed by product anxiety with a mean score of 19.25 , and the last category is stress anxiety with a mean score of 16.52 which belongs to anxiety component that had occurred less frequently to the students. From this finding, the categories can be classified into anxieties that are experienced by the students frequently and less frequently based on the overall mean score $(\mathrm{om}=18.54)$ where evaluation anxiety $(m=19.86)$ and product anxiety $(m=19.25)$ are the writing anxiety components that had been experienced by the students frequently. Meanwhile, stress anxiety is writing anxiety component that had been experienced by the students less frequently.

The findings reveal that the students had experienced fewer difficulties to begin to write that could lead them to procrastination and writers' block. Unfortunately, the students had evaluation anxiety frequently where the students felt that they would not be able to do their best as they believed that they do not have proper skills to write. This is also worsened by the fact that the students had experienced product anxiety that could lead the students to see that producing a piece of writing is not essential for them to (see Daly \& Miller, 1975). However, these findings 
should be confirmed further by seeing the average frequency of writing anxiety that had been experienced by the students (see Table 4) to see whether anxiety could facilitate or debilitate learning as shown in Table 2.

The results of the analysis of the writing anxiety questionnaire also provide the average frequency of writing anxiety that had been experienced by the students (see Table 4). Here, the frequencies were classified into high and low frequencies based on the overall mean score of the item of the writing anxiety questionnaire, that is, 2.32 .

Table 4: Average frequencies of writing anxiety with standard deviations

\begin{tabular}{|c|c|c|c|}
\hline Categories & No. & Mean & SD \\
\hline \multirow{8}{*}{ Evaluation } & 1 & 2.67 & 0.93 \\
\hline & 7 & 3.08 & 0.82 \\
\hline & 11 & 2.22 & 0.92 \\
\hline & 13 & 2.57 & 0.77 \\
\hline & 15 & 2.93 & 0.94 \\
\hline & 18 & 2.11 & 0.94 \\
\hline & 21 & 2.07 & 0.9 \\
\hline & 23 & 2.22 & 0.92 \\
\hline \multirow{7}{*}{ Stress } & 2 & 2.23 & 0.76 \\
\hline & 4 & 2.49 & 0.92 \\
\hline & 10 & 2.65 & 0.88 \\
\hline & 14 & 2.8 & 0.87 \\
\hline & 17 & 2.41 & 0.84 \\
\hline & 20 & 2 & 0.8 \\
\hline & 24 & 1.93 & 0.66 \\
\hline \multirow{9}{*}{ Product } & 3 & 1.89 & 0.86 \\
\hline & 5 & 2.21 & 0.87 \\
\hline & 6 & 1.78 & 0.82 \\
\hline & 8 & 2.74 & 0.86 \\
\hline & 9 & 2.05 & 0.8 \\
\hline & 12 & 2.14 & 0.74 \\
\hline & 16 & 2.14 & 0.74 \\
\hline & 19 & 1.74 & 0.9 \\
\hline & 22 & 1.75 & 0.79 \\
\hline \multicolumn{2}{|l|}{ Overal Mean } & 2.32 & 0.85 \\
\hline
\end{tabular}

Note:

Gray $\quad=$ low frequency

Transparent $=$ high frequency

Table 4 shows that there are 10 items of forms of writing anxiety that had been experienced frequently by the students. The items are: $1,7,13,15,4,10,14,17,8$, and 16 . Then, there are 14 items of forms of writing anxiety that had been experienced by the students less frequently. The items are: $11,18,21,23,2,20,24,3,5,6,9,12,19$, and 22 . Some statements that occur frequently provide the indications of evaluation anxiety. 
The mean scores shown above reveal that the students had evaluation anxiety frequently as informed earlier in Table 3. This is indicated by the students' disagreement to the statement that they could write a good text easily $(\mathrm{m}=3.08)$ as they thought that they could not write like other people $(m=2.93)$ and had difficulties to write down their ideas clearly $(m=2.67)$ and lack of confident to write and show it to the readers $(m=2.57)$. However, it does not mean that the students always experience evaluation anxiety that could debilitate them in learning writing because two positive statements indicate that the students could deal with evaluation anxiety. Here, the students chose the statement that they wanted their peers to read their texts $(\mathrm{m}=2.22)$ and the students would also want their texts to be read by the lecturer for feedback $(m=2.11)$.

The second category or component that is mostly experienced by the students is product anxiety. This category shows that producing a piece of writing can be considered not important by the students. The students will only write a single text without doing any revisions (see Daly \& Miller, 1975). Some statements that occur frequently provide the indications of product anxiety. Here, the students chose anxious when they submit their texts to get a grade $(m=2.74)$; and the students mainly disagreed with the statement that they spend their times for writing outside the class $(m=2.14)$. There are also some positive statements that indicate the students can deal with product anxiety where the students chose the statement that writing a text brings enjoyment $(\mathrm{m}=$ 2.21). The students also chose to revise their texts to make better texts $(\mathrm{m}=2.05)$ and they were not anxious to submit their assignments $(\mathrm{m}=2.14)$.

The last category that occurs less frequently to the students is stress anxiety. This component or category shows that students feel fear to begin to write. Due to the stress, the students may procrastinate and experience writers' block (Daly \& Miller, 1975; Musolino, 2007; Sirois, 2014; Steel, 2007). Some statements that occur frequently provide the indications of stress anxiety such as the students thought that they had no capacity to write $(\mathrm{m}=2.8)$. The students also had difficulties to organize their ideas $(m=2.65)$, to generate ideas $(m=2.49)$, and to write it in English $(\mathrm{m}=2.41)$. On the other hand, some positive statements indicate that the students could deal with stress. Here, the students did not feel hesitate to write down their ideas as they liked to write $(\mathrm{m}=2)$ and enjoyed writing their ideas $(\mathrm{m}=1.93)$.

\subsection{Discussion}

In terms of the components of writing anxiety (see Table 4), the students experienced anxiety in evaluation (mean score of 19.86) where the students felt had limited capacity to write that lead to lack of confident to write; product anxiety (mean score 19.25) where the students had not prioritized writing, and stress anxiety (16.52) where the students had difficulties to begin to write that would lead to procrastination.

The findings are in line with a previous study by Ariyanti (2017) who also found out that limited capacity to write could lead to lack of confidence. The participants also avoided writing tasks as they had no ideas to write. Another thing is, a similar study conducted by Hidayati (2018) also revealed that evaluation is the main factor or component of anxiety in learning the English language. This point shows that anxiety could debilitate the students in performing and learning writing skills. This point is also supported by many previous studies where anxiety gave negative effects to students' performance in learning the skills of the English language such as speaking (Aghajani \& Amanzadeh, 2017; Anandari, 2015; Sutarsyah, 2017) and writing (Kusumaningputri et al., 2018; Rahim et al., 2016; Wahyuni \& Umam, 2017). 
The findings are possible to understand as the participants were the second-semester students who were new to the concept of writing at the university level. Writing at the university level demands the students to have the knowledge of a particular schematic structure and linguistic features (Emilia, 2009; Emilia \& Hamied, 2015). This is in line with a previous study by Sundari \& Febriyanti (2017) who found out that advanced students had lower writing anxiety as they had better capacity in writing

Apparently, this study does not see writing anxiety as a debilitating factor solely. Instead, in many ways, anxiety could also facilitate learning as Table 4 shows that positive statements occurred in the components used in this study as well. To be specific, Table 2 shows that more than fifty percent of the students were categorized as low anxious students. In other words, the students were able to deal with their writing anxiety, even though there are more negative statements which were described in this study instead of positive statements for each indicator of the writing anxiety.

This leads to a point that anxiety does not always debilitate writing performance. In certain points, anxiety could facilitate learning (Dörnyei, 2005; Reigstad, 1985). Also, this finding is in line with a previous study by Miri \& Joia (2018) who discovered that writing anxiety could be facilitating and debilitating the students' capability in writing in the English language. This could happen due to limited practices and activities that the students have done.

Furthermore, students should see anxiety not only from its negative effects but also see its positive effects. For example, a student may feel anxious when they are asked to submit their written works to the lecturer to be evaluated. If the students learn to deal with the issue, they could help themselves to learn better as the written tasks will be evaluated and given feedback. But, when the students do the opposite way where they do not want to submit their written tasks, this will lead to higher anxiety that will hinder their performance (see Aubrey, 2011; Tran \& Moni, 2015).

Accordingly, students should learn to see how being anxious could help them to excel in learning as facilitating anxiety could help someone to be inspired to reach excellence (Aghajani \& Amanzadeh, 2017; Javid, 2014; Miri \& Joia, 2018; Rudiyanto, 2017). However, it does not mean that every student is able to keep himself or herself motivated. This is where lecturers and classmates should provide guidance and motivation to the students or peers in teaching and learning activities. The students cannot be forced to do something. When the lecturer or their classmates do that, the writing anxiety will hinder their performance as Dörnyei $(2005$, p. 198) states that "anxiety affects L2 performance."

\section{Conclusions}

This study aims to explore the EFL students' writing anxiety. The students were from a private university in Pontianak, West Kalimantan, Indonesia. After having the entire process of the research, the writer would like to point out a conclusion. The students experienced writing anxiety in certain points in terms of stress, evaluation, and product. The writing anxiety experienced by the students could be debilitating and facilitating them in learning writing.

To be specific, the students who regard writing as not useful or do not believe with their own capacities will make them feel fear to write. This will lead the students to procrastinate or having writer's block. On the other hand, the students who believe with their own capacities and believe 
that their lecturer and classmates can help them to improve their writing skills will make the students feel confident to write.

\section{References}

Aghajani, M., \& Amanzadeh, H. (2017). The effect of anxiety on speaking ability: An experimental study on EFL learners. Journal of Applied Linguistics and Language Research, 4(7), 154-264.

Anandari, C. L. (2015). Indonesian EFL students' anxiety in speech production: Possible causes and remedy. TEFLIN Journal - A Publication on the Teaching and Learning of English, 26(1), 1. https://doi.org/10.15639/teflinjournal.v26i1/1-16

Ariyanti, A. (2017). Foreign language anxiety in academic writing. Dinamika Ilmu, 17(1), 143152. https://doi.org/10.21093/di.v17i1.815

Aubrey, S. (2011). Facilitating Interaction in East Asian EFL Classrooms: Increasing Students' Willingness to Communicate. Language Education in Asia, 2(2), 237-245. https://doi.org/10.5746/LEiA/11/V2/I2/A06/Aubrey

Cheng, Y.-S. (2004). A measure of second language writing anxiety: Scale development and preliminary validation. Journal of Second Language Writing, 13(4), 313-335. https://doi.org/10.1016/j.jslw.2004.07.001

Çocuk, H. E., Yelken, T. Y., \& Özer, Ö. (2016). The relationship between writing anxiety and writing disposition among secondary school students. Eurasian Journal of Educational Research, 16(63), 335-352. https://doi.org/10.14689/ejer.2016.63.19

Cohen, L., Manion, L., \& Morrison, K. (2007). Research methods in education (6th ed). London ; New York: Routledge.

Creswell, J. W. (2012). Educational research: Planning, conducting, and evaluating quantitative and qualitative research (4th ed.). Boston, MA: Pearson.

Daly, J. A., \& Miller, M. D. (1975). The empirical development of an instrument to neasure writing apprehension. Research in the Teaching of English, 9(3), 242-249.

Dörnyei, Z. (2005). The Psychology of the language learner: Individual differences in second language acquisition. Mahwah, NJ: Lawrence Erlbaum Associates.

Emilia, E. (2005). A critical genre-based approach to teaching academic writing in a tertiary EFL context in Indonesia (Unpublished Dissertation, The University of Melbourne). Retrieved from https://minerva-access.unimelb.edu.au/handle/11343/39548

Emilia, E. (2009). Menulis tesis dan disertasi. Retrieved from http://alifviaarviningrum.studentsblog.undip.ac.id/files/2010/10/Tesis-dan-Disertasi-9-Rev-Sept08.pdf

Emilia, E. (2010). Teaching writing: Developing critical learners. Bandung, Indonesia: Rizqi Press.

Emilia, E., \& Hamied, F. A. (2015). Systemic functional linguistic genre pedagogy (SFL GP) in a tertiary EFL writing context in Indonesia. TEFLIN Journal, 26(2), 155. https://doi.org/10.15639/teflinjournal.v26i2/155-182

Fareed, M., Ashraf, A., \& Bilal, M. (2016). ESL learners' writing skills: Problems, factors and suggestions. Journal of Education \& Social Sciences, 4(2), 83-94. https://doi.org/10.20547/jess0421604201

Fraenkel, J. R., Wallen, N. E., \& Hyun, H. H. (2011). How to design and evaluate research in education (8th ed.). New York: McGraw-Hill Humanities/Social Sciences/Languages. 
Grabe, W., \& Kaplan, R. B. (1998). Theory and practice of writing: An applied linguistic perspective (3rd ed.). New York: Addison Wesley Longman.

Hidayati, T. (2018). Student language anxiety in learning English (A survey to non-English major students in rural area). IJELTAL (Indonesian Journal of English Language Teaching and Applied Linguistics), 2(2), 95-113. https://doi.org/10.21093/ijeltal.v2i2.55

Horwitz, E. K., Horwitz, M. B., \& Cope, J. (1986). Foreign language classroom anxiety. The Modern Language Journal, 70(2), 125-132. https://doi.org/10.2307/327317

Javid, C. Z. (2014). Measuring language anxiety in an EFL context. Journal of Education and Practice, 5(25), 180-192-192.

Klimova, B. F. (2014). Constraints and difficulties in the process of writing acquisition. Procedia - Social and Behavioral Sciences, 122, 433-437. https://doi.org/10.1016/j.sbspro.2014.01.1367

Kurt, G., \& Atay, D. (2007). The effects of peer feedback on the writing anxiety of prospective Turkish teachers of EFL. Journal of Theory and Practice in Education, 3(1), 12-23.

Kusumaningputri, R., Ningsih, T. A., \& Wisasongko, W. (2018). Second language writing anxiety of Indonesian EFL students. Lingua Cultura, 12(4), 357-362. https://doi.org/10.21512/lc.v12i4.4268

Miri, M. A., \& Joia, J. (2018). Writing anxiety in an Afghan EFL setting: Voices from five Afghan students. Journal of Foreign Languange Teaching and Learning, 3(1), 14-29. https://doi.org/10.18196/ftl.3125

Musolino, E. (2007). The effect of procrastination and stress on low effort and high effort tasks. The Huron University College Journal of Learning and Motivation, 45(1). Retrieved from https://ir.lib.uwo.ca/hucjlm/vol45/iss1/13

Oshima, A., \& Hogue, A. (1999). Writing academic English (3rd ed.). New York: Addison Wesley Longman.

Piniel, K., \& Csizér, K. (2013). L2 motivation, anxiety and self-efficacy: The interrelationship of individual variables in the secondary school context. Studies in Second Language Learning and Teaching, 3(4), 523. https://doi.org/10.14746/ssllt.2013.3.4.5

Rahim, S. A., Jaganathan, P., \& Mahadi, T. S. T. (2016). An investigation on the effects of writing anxiety on readiness of writing among low proficiency undergraduates. $5,11$.

Reigstad, T. J. (1985). Perspectives on anxiety and the basic writer: Research, evaluation, and instruction. Journal of Basic Writing, 4(1), 68-77.

Rudiyanto, M. (2017). English writing anxiety toward Indonesian EFL learners: A descriptive study. INTERAKSI Jurnal Kependidikan, 12(2). Retrieved from http://ejournal.unira.ac.id/index.php/jurnal_interaksi/article/view/364

Sirois, F. M. (2014). Procrastination and stress: Exploring the role of self-compassion. Self and Identity, 13(2), 128-145. https://doi.org/10.1080/15298868.2013.763404

Steel, P. (2007). The nature of procrastination: A meta-analytic and theoretical review of quintessential self-regulatory failure. Psychological Bulletin, 133(1), 65-94. https://doi.org/10.1037/0033-2909.133.1.65

Sundari, H., \& Febriyanti, R. H. (2017). Writing apprehension in the writing class: Indonesian EFL learners context. DEIKSIS, 9(01), 34. https://doi.org/10.30998/deiksis.v9i01.863

Susoy, Z., \& Tanyer, S. (2013). A closer look at the foreign language writing anxiety of Turkish EFL pre-service teachers. Presented at the International Academic Conference on Education, Teaching and E-learning, Prague, Czech Republic. Retrieved from 
https://www.academia.edu/5158766/1_A_Closer_Look_at_the_Foreign_Language_Writing _Anxiety_of_Turkish_EFL_Pre-service_Teachers

Sutarsyah, C. (2017). An analysis of student's speaking anxiety and its effect on speaking performance. IJELTAL (Indonesian Journal of English Language Teaching and Applied Linguistics), 1(2), 143-152. https://doi.org/10.21093/ijeltal.v1i2.14

Toba, R., Noor, W. N., \& Sanu, L. O. (2019). The Current issues of Indonesian EFL students' writing skills: Ability, problem, and reason in writing comparison and contrast essay. Dinamika Ilmu, 19(1), 57-73. https://doi.org/10.21093/di.v19i1.1506

Tran, T. T. T., \& Moni, K. (2015). Management of foreign language anxiety: Insiders' awareness and experiences. Cogent Education, 2(1), 992593. https://doi.org/10.1080/2331186X.2014.992593

Wahyuni, S., \& Umam, M. K. (2017). An analysis on writing anxiety of Indonesian EFL college learners. JEELS (Journal of English Education and Linguistics Studies), 4(1), 105-128. https://doi.org/10.30762/jeels.v4i1.333

Williams, K. E. (2008). Is "Facilitating Anxiety" all in your head? Sophia Junior College Faculty Journal, 28, 1-7. 